\title{
Grå substans på avveie
}

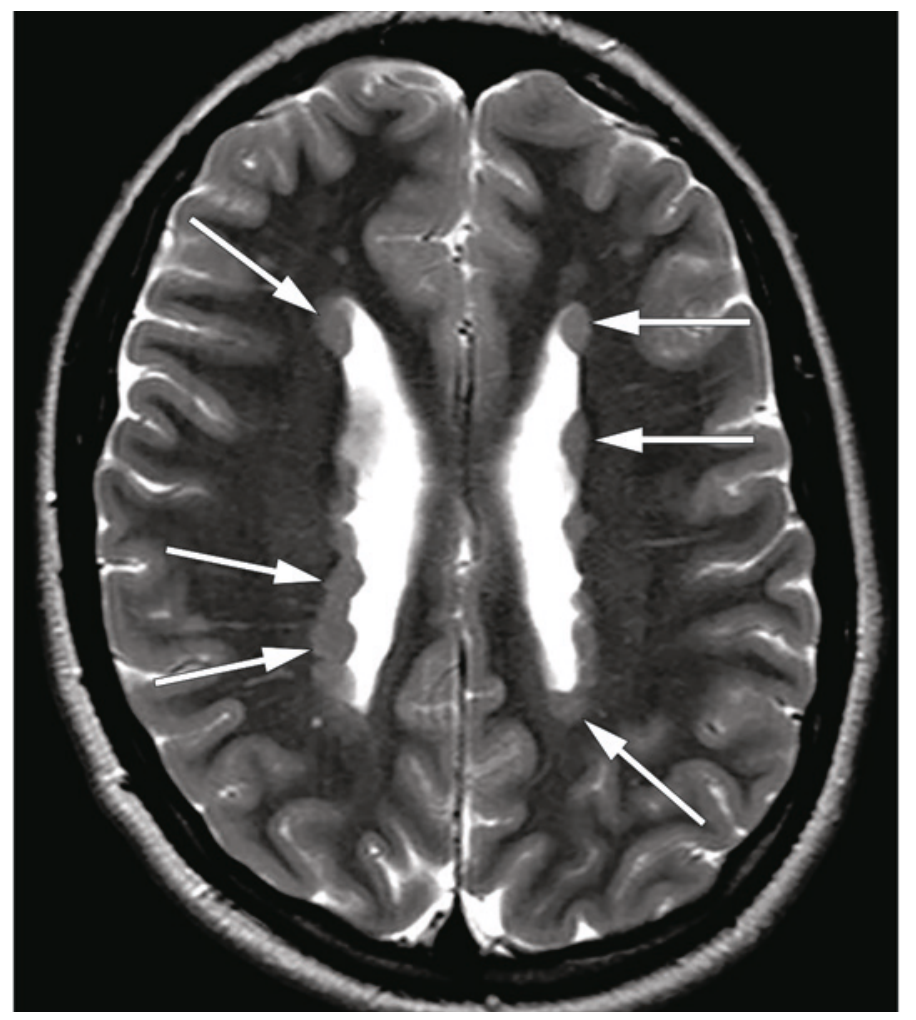

En jente i slutten av tenårene ble overflyttet til nevrologisk avdeling etter akutt innleggelse for et epilepsisuspekt anfall med generaliserte kramper og bevissthetstap. Hun hadde aldri tidligere hatt lignende anfall, men noen måneder $\mathrm{i}$ forkant hadde hun hatt to episoder med bevissthetstap tolket som synkoper. I forbindelse med dette ble hun utredet med 24-timers-EKG og 24-timers blodtrykksregistrering, som begge viste normale funn.

Standard elektroencefalogram (EEG) tatt etter overflyttingen var normalt, men magnetresonansundersøkelse (MR) av hodet etter epilepsiprotokoll viste utbredte forandringer. På bildet ser vi at aksial T2 gjennom øvre del av sideventriklene viser knuteformede formasjoner langs ventrikkelveggene. Funnene var forenlig med bilateral periventrikulær nodulær heterotopi.

Periventrikulær nodulær heterotopi er en migrasjonsforstyrrelse, det vil si en tilstand der cellevandringen under utviklingen av hjernen i fosterlivet ikke har funnet sted som forventet. Tilstanden oppstår mellom sjette og 24. svangerskapsuke og har ukjent insidens. «Heterotopi» refererer til forekomst av grupper med normale nevroner lokalisert på feil plass, i dette tilfellet grå substans som ikke har migrert til cortex cerebri, men blitt værende langs sideventriklene. Pasientene har som regel normal intelligens. Den van- ligste manifestasjonen av periventrikulær nodulær heterotopi er epilepsi, som ses hos $80-90 \%$. Denne kan debutere i alle aldre (1, 2). EEG-registrering med dybdeelektroder hos pasienter med periventrikulær nodulær heterotopi og epilepsi har vist at malformasjonene i seg selv kan være epileptogene (1).

De fleste pasientene har fokale anfall som oftest er svært behandlingsresistente. Spesielt i tilfeller der det blir påvist solitære, lett tilgjengelige malformasjoner kan kirurgisk behandling være aktuell. Periventrikulær nodulær heterotopi kan være genetisk betinget eller være forårsaket av intrauterin infeksjon eller iskemi. Tilstanden kan være ledd i syndromer med andre kongenitale anomalier. Flere gener kan være affisert, og det kliniske bildet avhenger av hvor mutasjonene er lokalisert $(1,2)$.

Pasienten har gitt samtykke til at artikkelen blir publisert.

\section{Line Broch}

line.epost@gmail.com

Nevrologisk avdeling

Drammen sykehus

\section{Bård Bjørnarå}

Radiologisk avdeling

Drammen sykehus

Karl-Friedrich Amthor

Nevrologisk avdeling

Drammen sykehus
Line Broch (f. 1974) er spesialist i nevrologi og overlege.

Forfatter har fylt ut ICMJE-skjemaet og oppgir ingen interessekonflikter.

Bård Torgeir Bjørnarå (f. 1970) er spesialist i radiologi, med spesialkompetanse i nevroradiologi og muskelskjelettradiologi, og overlege.

Forfatter har fylt ut ICMJE-skjemaet og oppgir ingen interessekonflikter.

Karl-Friedrich Amthor (f. 1950) er spesialist i nevrologi, dr.med. og seksjonsoverlege. Forfatter har fylt ut ICMJE-skjemaet og oppgir ingen interessekonflikter.

Litteratur

1. Leventer RJ, Guerrini R, Dobyns WB. Malformations of cortical development and epilepsy. Dialogues Clin Neurosci 2008; 10: 47-62.

2. Spalice A, Parisi P, Nicita F et al. Neuronal migration disorders: clinical, neuroradiologic and genetics aspects. Acta Paediatr 2009; 98: 421-33.

Mottatt 10.9. 2015, første revisjon innsendt 24.1 2016, godkjent 5.4. 2016. Redaktør: Lars Frich. 